UDC $579.22+279.26$

\title{
EXAMINING c-di-GMP AND POSSIBLE QUORUM SENSING REGULATION IN Pseudomonas fluorescens SBW25: LINKS BETWEEN INTRA- AND INTER-CELLULAR REGULATION BENEFITS COMMUNITY COOPERATIVE ACTIVITIES SUCH AS BIOFILM FORMATION
}

\author{
O. V. MOSHYNETS 1 , D. FOSTER ${ }^{2}$, S. A. KARAKHIM ${ }^{3}$, K. MCLAUGHLIN ${ }^{4}$, \\ S. P. ROGALSKY $Y^{5}$, S. Y. RYMAR ${ }^{1}$, G. P. VOLYNETS ${ }^{1}$, A. J. SPIERS ${ }^{4 凶}$ \\ ${ }^{1}$ Institute of Molecular Biology and Genetics, National Academy \\ of Sciences of Ukraine, Kyiv; \\ e-mail:moshynets@gmail.com; galina.volinetc@gmail.com \\ ${ }^{2}$ Nuffield Department of Medicine, University of Oxford, \\ John Radcliffe Hospital, United Kingdom; \\ e-mail:dona.foster@ndm.ox.ac.uk; \\ ${ }^{3}$ Palladin Institute of Biochemistry, National Academy \\ of Sciences of Ukraine, Kyiv; \\ e-mail: laserlab@biochem.kiev.ua; \\ ${ }^{4}$ School of Science, Engineering and Technology, Abertay University, United Kingdom; \\ e-mail: mclaughlinkimberley@gmail.com; \\ 凶e-mail: a.spiers@abertay.ac.uk; \\ ${ }^{5}$ Institute of Bioorganic Chemistry and Petrochemistry, \\ National Academy of Sciences of Ukraine, Kyiv; \\ e-mail: sergey.rogalsky@gmail.com
}

Bacterial success in colonizing complex environments requires individual response to micro-scale conditions as well as community-level cooperation to produce large-scale structures such as biofilms. Connecting individual and community responses could be achieved by linking the intracellular sensory and regulatory systems mediated by bis-(3'-5')-cyclic dimeric guanosine monophosphate (c-di-GMP) and other compounds of individuals with intercellular quorum sensing (QS) regulation controlling populations. There is growing evidence to suggest that biofilm formation by many pseudomonads is regulated by both intra and intercellular systems, though in the case of the model Pseudomonas fluorescens SBW25 Wrinkly Spreader in which mutations increasing c-di-GMP levels result in the production of a robust cellulose-based air-liquid interface biofilm, no evidence for the involvement of $Q S$ regulation has been reported. However, our recent review of the P. fluorescens SBW25 genome has identified a potential QS regulatory pathway and other QS-associated genes linked to c-di-GMP homeostasis, and QS signal molecules have also been identified in culture supernatants. These findings suggest a possible link between c-di-GMP and QS regulation in P. fluorescens SBW25 which might allow a more sophisticated and responsive control of cellulose production and biofilm formation when colonising the soil and plant-associated environments P. fluorescens SBW25 normally inhabits.

Ke y wo rd s: cyclic dimeric guanosine monophosphate (c-di-GMP), acyl homoserine lactone (AHL), bacterial cellulose, biofilms, Pseudomonas, quorum sensing (QS).

$\mathrm{T}$ he formation of biofilms is often considered an exemplar of cooperation within bacterial communities, though cooperation is always balanced by competition within the developing community $[1,2]$. Biofilm formation involves the co-ordinated attachment of founder cells to an appropriate

(C) 2018 Moshynets O. V. et al. This is an open-access article distributed under the terms of the Creative Commons Attribution License, which permits unrestricted use, distribution, and reproduction in any medium, provided the original author and source are credited. 
surface and the production of valuable extracellular polysaccharides (or extracellular polymeric substances, EPS) which forms the matrix of the biofilm structure. In the context of bacterial social evolution theory, EPS is considered a 'public goods' produced at a cost to the individual producer but providing an over-all benefit to the community as a whole. In many cases, biofilm formation has been shown to be controlled by quorum sensing (QS) regulation, a form of bacterial communication mediated by small diffusible signalling molecules [3-6], in which all members of the community invest and benefit equally and the community simultaneously protected against cheaters. However, there are cases in which physiological signals or genetic mutation activates biofilm formation, and the clonal expansion of the induced wild-type or mutant cells results in the developing structure. In this scenario, the benefit of biofilm formation outweighs the costs of production, resulting in a fitness advantage that selects for the induced wild-type or mutant cells over other nonbiofilm-forming competitors including potential cheaters (in some cases the benefits of EPS production may be preferentially directed at the producing cells and be relatively un-exploitable by cheaters [7]). Furthermore, cooperative behaviours resulting from QS, physiological induction or mutation would be expected to play a part in the of a development and success broader continuum of bacterial aggregations which includes colonies, flocs, slimes, etc., as well as the in vitro biofilms commonly studied using flow cells or microtitre plates [8].

In this article, we review the Wrinkly Spreaders (WS), one class of adaptive mutants which arise during the experimental evolution of populations of Pseudomonas fluorescens SBW25 in static liquid microcosms [9]. Wrinkly Spreaders produce a cellulose matrix-based biofilm at the air-liquid (A-L) interface, providing better access to oxygen, faster growth rates and improved fitness compared to the ancestor and other non-biofilm-forming competitors $[10,11]$. The underlying molecular biology of the Wrinkly Spreaders is well understood, with mutations causing an increase in c-di-GMP (bis$\left(3^{\prime}-5^{\prime}\right)$-cyclic dimeric guanosine monophosphate) levels resulting in enhanced cellulose production and stronger biofilm formation. Most notably for a pseudomonad, however, was that QS regulation was not found to be directly involved in this process though QS has yet to be systematically examined in P. fluorescens SBW25.
Recently a linkage has been reported between c-di-GMP and QS regulation in other pseudomonads [12-14] and other bacteria (e.g. Burkholderia and Vibrio $[15,16])$, and this has driven us to re-examine the P. fluorescens SBW25 genome for potential QSrelated genes and culture supernatants for QS signals. Here we suggest how P. fluorescens SBW25 might use QS regulation to further refine cellulose production and biofilm formation in natural environments (as opposed to in vitro microcosms), and consider more generally the benefits of linking the sensory and regulatory systems of individuals with the QS-based cooperative activity of populations and communities.

\section{Pseudomonas fluorescens SBW25 and the rise of the Wrinkly Spreaders}

P. fluorescens SBW25 is a soil and plant-associated pseudomonad originally isolated from a sugar beet (Beta vulgaris) leaf [17], and is able to colonise the leaf and root surfaces of a range of different cultivated plants and weeds. The 6.7 Mbp genome was initially mapped by Southern analysis before the complete genome sequence was obtained [17-19]. $P$. fluorescens SBW25 has been used to investigate plant and soil-microbe interactions, regulation and metabolism, biofilm formation and experimental evolution studies [10, 11, 20-22]. In the latter, bacterial populations are grown in artificial environments known as microcosms and subject to varied selective pressures [20, 23-25]. One aim of this is to provide mechanistic explanations linking adaptive mutation and the underlying molecular biology of an organism with the fitness improvements of 'evolved' mutants compared to the ancestral strain.

Wild-type $P$. fluorescens SBW25 produces smooth round colonies on agar plates, and will grow throughout the liquid column of static microcosms over a period of several days. However, during this time the expanding population will radiate and accumulate a variety of mutants including WS [10, 11]. These are a class of mutants characterised by a flattened, wrinkled colony morphology and the ability to produce a robust and well-attached biofilm at the A-L interface of static microcosms (these characteristics are collectively known as the WS phenotype) (Fig. 1). Although most biofilm research has focussed on liquid-solid surface (L-S) interface biofilms formed by bacteria in laminar flow cells or in micro-titre plates [26-28], the ability to form biofilms at the A-L interface is common amongst 

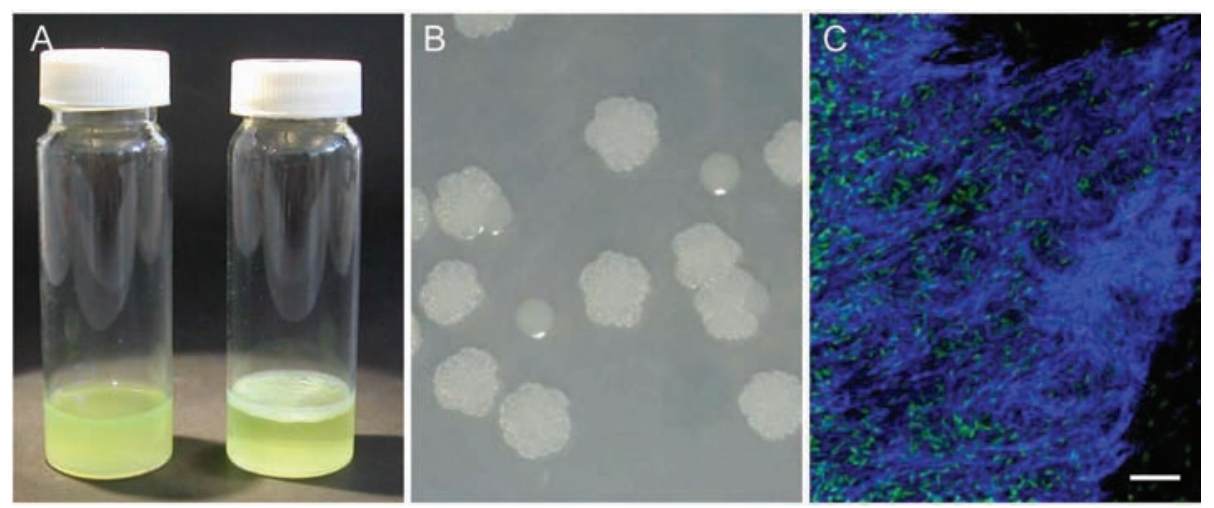

Fig. 1. The Wrinkly Spreader produces a biofilm in static microcosms and wrinkled colonies on agar plates. Developing populations of P. fluorescens SBW25 in static microcosms will radiate and produce a number of mutants including the Wrinkly Spreaders (WS). (A) Wild-type P. fluorescens SBW25 grows in the liquid column of static microcosms (left) whereas Wrinkly Spreaders produce a robust biofilm at the air-liquid (AL) interface. The microcosms are $30 \mathrm{ml}$ Universal glass vials with $6 \mathrm{ml}$ liquid growth medium and are typically incubated for 3 days to allow biofilm-formation. (B) The Wrinkly Spreader forms wrinkled colonies readily distinguished from wild-type round and smooth colonies on agar plates. (C) Both the WS biofilm and colony contain extensive networks of extracellular cellulose fibres. Shown here is a confocal laser scanning microscopy (CLSM) image of a WS biofilm sample stained with Calcofluor show visualise cellulose (blue) surrounding green fluorescent protein (GFP)-expressing WS cells (green). These images were taken using a Carl Zeiss LSM-510 CLSM and the scale bar indicates $5 \mu \mathrm{m}$

environmental pseudomonads [29-32]. Many abiotic and biotic factors influencing L-S and A-L interface biofilm-formation are the same and probably impact on other types of bacterial aggregation too [8].

Wrinkly Spreaders are adaptive mutants in static microcosms containing King's B (KB) liquid growth medium [33], and show improved competitive fitness (W) compared to the wild-type P. fluorescens SBW25 ancestor and other non-biofilmforming competitors ( $\mathrm{W}=1.5-2.5[9,34,35])$ ( $\mathrm{W}$ is the ratio of Malthusian parameters for continuously growing populations and by definition, adaptive mutants will have a competitive fitness (W) advantage over the ancestor, i.e. $\mathrm{W}>1$; when $\mathrm{W}=1$, the two strains are neutral with respect to one another, and when $\mathrm{W}<1$ the mutant is at a disadvantage). However, in shaken microcosms where biofilms cannot form, or on agar plates where the WS phenotype is unstable, the fitness of Wrinkly Spreaders is much reduced and at times even lower than the ancestor $(\mathrm{W}=0.1-1.0[34-36])$.

The evolutionary and ecological success of the Wrinkly Spreader is explained by the ability to rapidly colonise the A-L interface of static microcosms by biofilm-formation, allowing it to intercept oxygen $\left(\mathrm{O}_{2}\right)$ diffusing into the liquid from the air above $[37,38]$. P. fluorescens SBW25 is an aerobe that grows more slowly under micro-aerobic conditions. The initial colonists of static microcosms rapidly establish a strong $\mathrm{O}_{2}$ gradient through the up-take of $\mathrm{O}_{2}$, effectively dividing their environment into an $\mathrm{O}_{2}$-rich zone at the A-L interface and an $\mathrm{O}_{2}$-depleted zone below (in this respect, wild-type P. fluorescens SBW25 is responsible for niche construction [11, 39]). Since growth is $\mathrm{O}_{2}$-limited in these microcosms, bacteria located at the A-L interface will grow faster than those below. As Wrinkly Spreaders can colonise the A-L interface without the constant need for swimming by biofilm-formation, better access to $\mathrm{O}_{2}$ and higher growth rates provide the fitness advantage, allowing them to outcompete the ancestor and other non-biofilm-forming competitors [37]. Growth at the A-L interface clearly impacts on metabolism, as bacteria recovered from within and underneath biofilms can be differentiated by Raman spectroscopy [40]. In ecological terms, the A-L interface can also be thought of as unoccupied niche and colonisation of this space by biofilm-forming Wrinkly Spreaders would avoid the constant competition between the wild-type P. fluorescens SBW25 ancestor and other non-biofilm-forming competitors in the $\mathrm{O}_{2}$-depleted niche below.

Wrinkly Spreader lineages (i.e. subpopulations) arise in communities, founded by wild-type $P$. fluo- 
rescens SBW25 and containing numerous other mutant lineages, in which there is both inter-lineage and intra-lineage completion. This type of complex interaction is described by the Red Queen hypothesis in which all genotypes are locked into constant competition against one another [41]. In this type of community, the Wrinkly Spreader fitness advantage is negative-frequency dependent: at low relative numbers they have a significant advantage and are largely competing against non-biofilm-forming lineages. In this situation the cooperative activity within the WS lineage that forms the biofilm might be better explained by the Black Queen hypothesis where genotypes are mutually dependent [42]. However, as Wrinkly Spreader numbers grow, completion within the WS lineage increases, reducing the fitness advantage for all Wrinkly Spreaders.

In bacterial social evolution theory, biofilms are considered common or public goods in which individual bacteria are expected contribute to the costly EPS matrix through cooperative social behaviour [1, 2, 43, 44]. However, this apparent cooperation might actually result from one or more of three mechanisms, including the response of individual bacteria to environmental stimuli, a community response to QS regulation, and mutation overriding normal regulatory systems (Fig. 2). This cooperation is explained by Hamilton's inclusive fitness (or kin selection theory) which states that cooperation evolves between genetically related individuals [44], and could be facilitated by commonality of sensory systems and QS regulation in which all sufficiently-related individuals respond to the same signals, or to the clonal expansion of a single mutant lineage.

Unlike many other pseudomonads, P. fluorescens SBW25 has not been shown to use QS regulation and therefore appears inquorate. Perhaps uniquely, biofilm-formation by Wrinkly Spreaders has been shown to be the result of genetic mutation and clonal expansion, rather than by the cooperative effort of a community.

\section{Unravelling the underlying molecular biology of the Wrinkly Spreader}

Mini-transposon mutagenesis of the archetypal Wrinkly Spreader, a particular WS isolate also known as the Large Spreading Wrinkly Spreader (LSWS) and strain PR1200, was used to identify the key genes and regulatory pathways responsible for the WS phenotype [10, 34, 35]. Two key operons, referred to as wss (WS structural operon) and wsp
(WS phenotype regulatory operon), were found to be essential for the WS phenotype.

The ten gene wss operon (wss $A-J$ ) encodes a bacterial cellulose synthase, with the core subunits encoded by WssB, WssC, WssD, and WssE [34]. Cellulose was first reported to be produced by Acetobacter xylinus (now known as Gluconacetobacter hansenii) in a thick, buoyant biofilm, and it is also

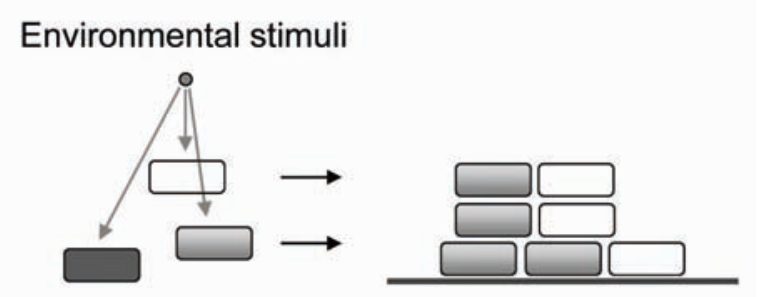

\section{Quorum sensing}

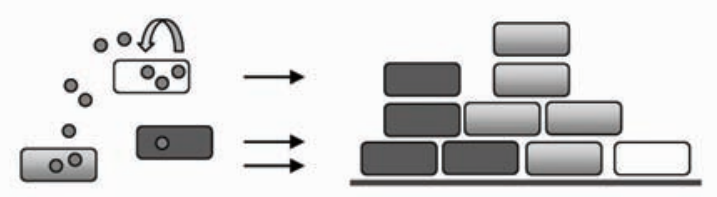

\section{Mutation}

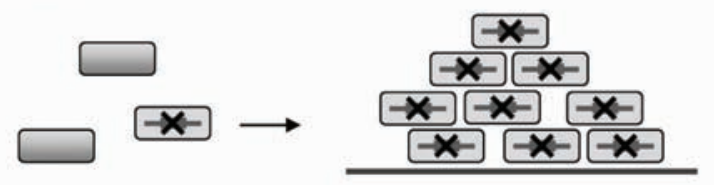

Fig. 2. Three routes leading to the formation of biofilms. Biofilms might be the result of communities of bacteria all responding to the same environmental stimuli (top), quorum sensing (QS) regulation (middle), or mutation (bottom). The initiation of biofilmformation might be the result of the detection of a signal by all individuals indicating that conditions are appropriate for settlement and growth. Alternatively, QS signals produced by a few individuals might then commit the entire community to biofilmformation, or mutation in one individual could induce the appropriate behaviour. In the first two situations, variation within the community (from minor genotype differences between lineages or subpopulations to species differences, indicated by white, grey and black fillings) will result in a heterogeneous biofilm-founding population. However, in the case of mutation, the biofilm will be produced by the clonal expansion of the mutant lineage with no heterogeneity in the early stages of biofilm-formation 
produced in substantially lower amounts by enteric bacteria such as Escherichia coli K-12 and Salmonella enteritidis 3934 [32, 46, 47]. In Escherichia, Gluconacetobacter and Salmonella spp., the genes required for cellulose production are contained within bacterial cellulose synthase (bcs) operons similar to the P. fluorescens SBW25 wss operon [34], though $b c s$ operon duplications and other rearrangements are common [48]. Unlike most bcs operons however, the $P$. fluorescens SBW25 wss operon also encodes proteins involved in the acetylation of cellulose $(W s s F-I)[34,49,50]$ which are also found in several closely-related Pseudomonas plant pathogens as well as in the bird pathogen Bordetella avium 197N [49, 51, 52]. This unusual modification of the polymer by P. fluorescens SBW25 was proven by purifying EPS from WS biofilms and subsequent chemical composition and linkage analysis [49].

Cellulose fibres and clumps could also be visualised in WS biofilm samples by fluorescent or confocal laser scanning microscopy [32, 49, 53] (Fig. 1). Mini-transposon insertions in wss $A-E$ abolished cellulose production and the WS phenotype, whereas insertions in $w s s F-I$ resulted in the production of un-acetylated cellulose and a partial WS phenotype $[34,45,49,54]$. In contrast, mutation of wssJ had no impact, suggesting that the last gene in the wss operon may be redundant [45]. Furthermore, like several other pseudomonad biofilms, the WS biofilm contains extracellular DNA which may also contribute to biofilm strength and resilience $(\mathrm{O}$. Moshynets et al. unpublished observations; to be published elsewhere).

The seven gene wsp operon ( $w s p A-F, R$ ) encodes a chemosensory-like complex in which the receipt of an unknown environmental signal results in the activation of WspR, a GGDEF-domain containing diguanylate cyclase (DGC) response regulator $[34,55,56]$. Activated WspR synthesises c-di-GMP from GTP [57]. C-di-GMP had been earlier identified as a regulator of cellulose synthase activity in Gluconacetobacter spp. [58] and is an important intracellular regulator found in many bacterial species. Intracellular concentrations of c-di-GMP is mediated by the opposing actions of two types of enzymes: DGCs containing GGDEF-domains that synthesize c-di-GMP, and phosphodiesterases (PDEs) containing EAL or HD-GYP domains that degrade c-diGMP. Levels of c-di-GMP influence a wide range of phenotypes including cellular responses that effect pathogenesis, motility, secretion, cytotoxicity, syn- thesis of secondary metabolites and environmental stress adaptation as well as QS [59-62]. Many of these phenotypes are also regulated by the Gac/Rsm master regulon, and recently links between the c-diGMP and Gac/Rsm networks have been identified in $P$. aeruginosa PAK [63] (the Gac/Rsm regulon is also present in P. fluorescens SBW25 [64]). Modulation of c-di-GMP is also associated with control of motility, biofilm formation through adhesion and EPS production, including cellulose, and other social behaviours.

The nature of the Wsp complex and the link to cellulose production through c-di-GMP suggested a model explaining the WS phenotype [56]. In this, mutations in Wsp subunits that increased WspR activation in the absence of the normal environmental signal were predicted to result in the expression of the WS phenotype (Fig. 3). The model was confirmed by the identification of a $w s p F$ (S301R) mutation in the archetypal Wrinkly Spreader, close to the active site and predicted to reduce the methylesterase activity of the subunit required to limit WspR activation. Allelic replacement experiments in which the $w s p F$ mutation was changed to the wild-type sequence and vice versa confirmed that this mutation was sufficient to explain the WS phenotype [56]. Further analysis of other independently-isolated Wrinkly Spreaders identified additional mutations in $w s p F$ and $w s p E$, as well as in several other DGCs or DGC-associated loci (aws and $m w s$ ), all of which are predicted to result in increased levels of c-di-GMP and the expression of the WS phenotype [56, 65, 66] (exogenous Fe can non-specifically induce cellulose production by $P$. fluorescens SBW25 and the formation of a weak, poorly attached biofilm [67]). A total of 39 GGDEF-domain containing proteins have been identified in P. fluorescens SBW25 genome [18], and the activation of some of these by intra- and intergenic mutations in negative regulators of the DGC or the DGCs themselves can also activate the WS phenotype in a $\Delta a w s \Delta m w s \Delta w s p$ triple-deletion mutant [68] (loss of function mutations often lead to bacterial adaptation to new conditions [69]). This strongly suggests that the c-di-GMP connection between the Wsp chemosensory-like complex and the Wss cellulose synthase is not unique, and any mutation occurring in radiating populations of P. fluorescens SBW25 in static microcosms that up-regulates c-di-GMP levels might result in Wrinkly Spreaders (mutations will arise and fix with a frequency corresponding to their ease of occurrence and fitness relative to other Wrinkly Spreader competitors). 


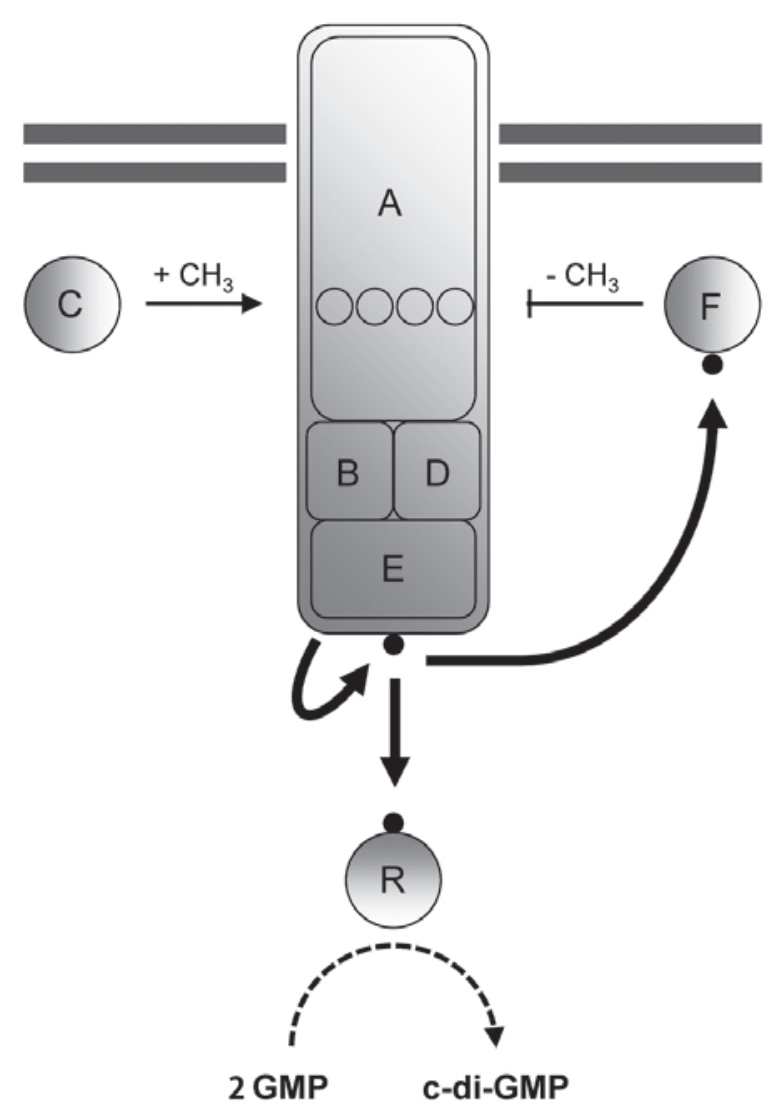

Fig. 3. The Wsp chemosensory complex is responsible for the synthesis of cyclic-di-GMP and the activation of the Wrinkly Spreader (WS) phenotype. A schematic showing the functioning of the Wsp complex is shown. The methyl-accepting chemotaxis protein (WspA), scaffold proteins (WspB and WspD) and histidine kinase (WspE) form a membrane-associated receptor-signalling complex. In the absence of an appropriate environmental signal, the complex is silent. Upon activation by phosphorylation (indicated by the black circles), the di-guanylate cyclase (DGC) response regulator (WspR) synthesizes cdi-GMP from GTP. The system is controlled by the opposing activities of a methyltransferase (WspC) and methylesterase (WspF), which add and remove, respectively, methyl $\left(\mathrm{CH}_{3}\right)$ groups on the signalling domain of WspA (circles). In wild-type P. fluorescens SBW25, the activities of the two are balanced, preventing the activation of $W s p R$ and allowing the Wsp complex to oscillate between active and inactive states. In many WS, mutations inhibiting WspF function or activating WspE kinase activity result in the activation of WspR and the production of cdi-GMP. Increased levels of c-di-GMP then lead to the expression of the WS phenotype. This figure is adapted from [9]
The WS model is not appropriate for the regulation of cellulose production by $\boldsymbol{P}$. fluorescens SBW25 in natural environments

Although the WS phenotype, including both competitive fitness and wrinkleality, is variable amongst independently-isolated Wrinkly Spreaders [70], it appears that WS activating mutations are binary in nature and result in the unregulated overproduction of cellulose and biofilm formation. In the soil and plant-associated environments colonised by P. fluorescens SBW25, greater responsiveness to environmental stimuli and flexibility in behaviour is required, and both cellulose production and biofilm formation are expected to be controlled by a complex network of regulatory systems. Some of these have been identified with wss operon transcription regulated by the DGCs AwsR and WspR, as well as by the master regulators of alginate (AlgR) and flagella (FleQ), during the colonisation of the Sugar beet rhizosphere where the ability to produce cellulose provides a fitness advantage for P. fluorescens SBW25 [71, 72]. However, the environmental stimuli these systems respond to have yet to be identified, and it is notable that QS regulation, involved in the regulation of EPS production and biofilm formation in many pseudomonads, has not been reported in P. fluorescens SBW25, nor have QS genes been identified in the analysis of Wrinkly Spreaders or P. fluorescens SBW25 rhizosphere colonisation.

\section{Challenging the view that \\ $P$. fluorescens SBW25 is inquorate}

Recently, a link between QS regulation and cdi-GMP has been identified in pseudomonads [1214]. It is generally assumed that the primary quorum signalling molecules or autoinducers that bind their cognate receptors to directly or indirectly activate gene expression used by Gram-negative bacteria are N-acyl-homoserine lactones (AHLs) [3-6]. Pseudomonads have been reported to produce a variety of different AHLs controlling the production of virulence factors, EPS, and motility that are important for bacterial adaptation and colonisation in a range of environments [73-76]. In P. aeruginosa PA14, the QS regulator LasR induces the expression of TpbA which in turn represses the DGC activity of TpbB, resulting in lowered c-di-GMP levels [77] (a slightly different $\mathrm{TpbB}$ analogue known as YfiR has also been investigated in P. aeruginosa PA01 [78]). This link drove us to examine the $P$. fluorescens SBW25 
genome for QS components which might also be linked to c-di-GMP homeostasis and therefore to cellulose synthesis and biofilm-formation (this analysis will be published elsewhere).

We have identified a potential AHL synthase homologue (PFLU0008), as well as homologues of LasR (PFLU1386) and TpbA (PFLU0050) in P. fluorescens SBW25, and hypothesize that they may form a QS regulatory pathway acting through WspR or other DGCs to repress cellulose production (Fig. 4). First, the presence of a HdtS-like AHL synthase homologue [73] suggests that $P$. fluorescens SBW25 might produce AHLs under the right conditions, and in preliminary experiments, we have detected at least two different AHL molecules in culture extracts using a standard AHL bio-reporter assay [79, 80]. Secondly, although P. fluorescens SBW25 was not originally annotated as having a LasR homologue [19], PFLU1386 is a putative regulator belonging to the same LuxR family of transcriptional regulators. Despite a poor level of homology (32\% ID, amino-acid level sequence identity), it has been possible to model the 3D structure of PFLU1386 using a LasR-AHL co-crystal template and dock several AHLs including DHL (N-dodeconyl-L-homoserine lactone, C12-HSL) and 3-O-DHL (N-(3oxo-dodecanoyl)-L-homoserine lactone, 3-O-C12HSL) (Fig. 5). This suggests that PFLU1386 might bind AHLs and induce the transcription of as-yet unidentified QS-dependent genes. Finally, the 3D structure of PFLU0050 can also be modelled using a TpbA crystal template [81], suggesting that these two proteins share a high degree of structural similarity, and that PFLU0050 may also show AHL-dependent tyrosine phosphatase activity and regulate a cognate TpbB-like DGC. Using the P. aeruginosa PA14 TpbB amino-acid sequence, we identified a possible TpbB homologue, PFLU5210 (62\% ID), which had previously been identified as AwsR which regulates wss operon transcription [65, 72]. PFLU0050 may also regulate the activity of AwsR as well as more distantly-related DGCs (e.g. WspR which shares 35\% ID with TpbB) to control c-di-GMP levels.

Our analysis of the $P$. fluorescens SBW25 genome has identified several other proteins that might play a role in QS regulation including some associated with alpha-hydroxy ketones (AHKs) which we have detected $P$. fluorescens SBW25 culture extracts using the Janthinobacterium sp. bio-reporter assay [82]. We have identified two potential AHK synthases (PFLU5220 and PFLU5614) and an AHK sensory protein (PFLU1736) in the P. fluorescens SBW25 genome, but have not identified a potential AHKdependent regulator. This suggests that the potential $P$. fluorescens SBW25 AHK pathway is more similar to the Vibrio pathway which also lacks a regulator, than for example, the Legionella pathway which includes one [83].

\section{Linking individual behaviour with community action}

Although biofilm-formation can result from mutation and the clonal expansion of adaptive mutant lineages, or through QS regulation, there are benefits in linking individual (intracellular) regulatory networks with community-based decision and

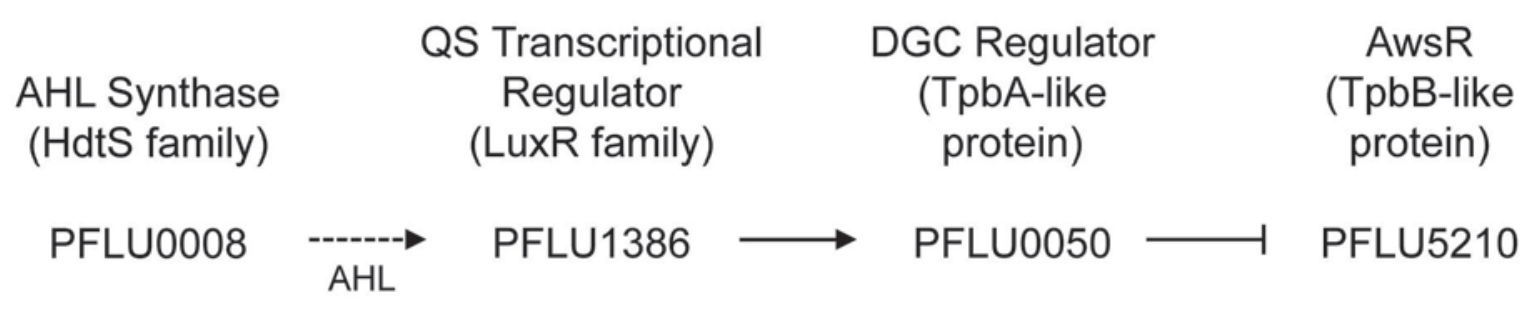

Fig. 4. P. fluorescens SBW25 may utilise QS to regulate cellulose production. A bioinformatics analyses of P. fluorescens SBW25 proteins has identified potential homologues which may act together to produce a QS regulatory pathway that might reduce the activity of the Wss cellulose synthase by modulating c-diGMP levels. The homologue of HdtS (PFLU0008) is predicted to synthesize AHLs which then bind to the LasR homologue (PFLU1386) in a QS manner. Bound PFLU1386 is predicted to induce transcription of the PFLU0050 gene resulting in the expression of a DGC regulator homologous to TpbA. PFLU0050 may then regulate the activity of the TpbB homologue (AwsR, PFLU5210). PFLU0050 might also repress the activity of other DGCs, possibly even WspR, to reduce c-di-GMP levels and repress cellulose production 


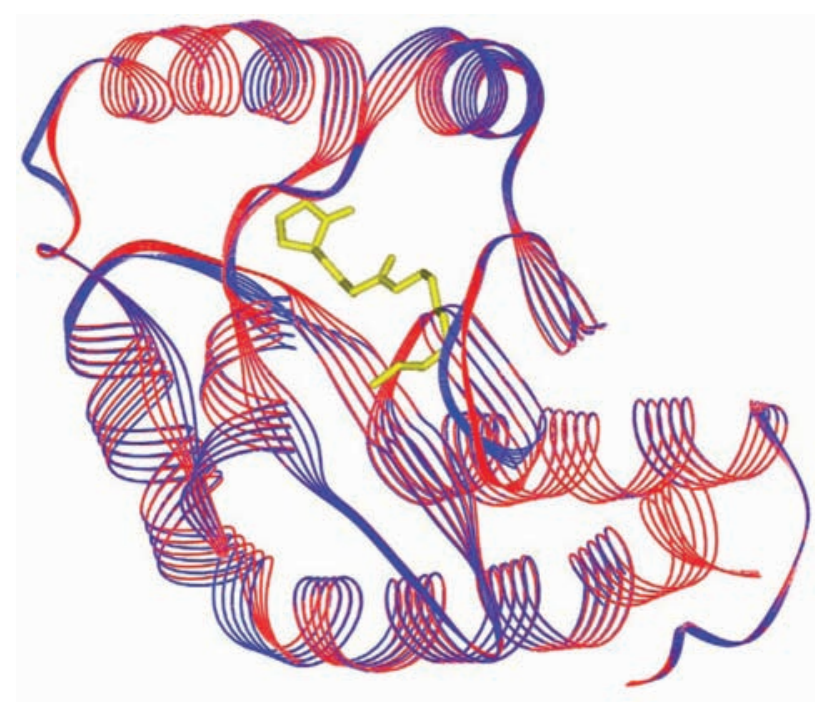

Fig. 5. PFLU1386 can be modelled to show AHL binding. The $3 D$ structure of the $P$. fluorescens SBW25 PFLU1386 LasR homologue can be modelled using as a template the structure determined for the P. aeruginosa LasR-3-O-DHL (N-(3-oxododecanoyl)-L-homoserine lactone) co-crystal (Molecular modeling database (MMDB) ID: 76777). Shown here is the superposition of the PFLU1386 homology model (blue) with the LasR (red) and 3-ODHL (yellow) co-crystal showing the high degree of structural similarity between the two proteins and relative position of the ligand-binding site. Both 3-O-DHL and DHL ( $N$-dodeconyl-L-homoserine lactone) can be docked into the corresponding active site in the PFLU1386 model, suggesting that either might be ligands for this protein

enforcement (Table). Bacteria have multiple and interacting regulatory networks which allow the appropriate response to environmental factors. For example, in pseudomonads, Fe-repressible and anaerobically (low $\mathrm{O}_{2}$ )-induced small RNA (sRNA) repressors interact with QS regulation, whilst other sRNAs sequester RNA-binding proteins that regulate global translational repressors, including central elements controlling motility, biofilm-formation, QS regulation, the expression of virulence factors, and the utilisation of carbon sources, some of which are also regulated by c-di-GMP levels [4, 13, 84]. Although bacteria within a fairly uniform environment might be expected to show the same behaviour, micro-heterogeneity in local conditions, variation in cellular status and stochastic responses would lead to phenotypic heterogeneity within populations [85] and mean that not all individuals would be in an ap- propriate condition to invest in community effort or to benefit from the results of such endeavours. Indeed, if all individuals do not benefit, cooperation can breakdown leading to a public goods dilemma: in both $P$. aeruginosa PA01 and Wrinkly Spreader populations, the presence of cheaters reduces overall fitness, growth and biofilm formation [86, 87] (though not in all cases, e.g. [7]).

However, links between intracellular regulators such as c-di-GMP with community-based (intercellular) QS regulation provide a mechanism allowing individuals to opt-in and opt-out of cooperative activity. In particular, individual sensing and decision allows opting in to the early stages of biofilm formation when benefits might be expected in the future (i.e. providing a fitness benefit to that particular lineage), and opting out when biofilms mature or are damaged, when further benefits to cooperative activity are no longer likely. One example of the need for an opt-out might be found in Ancestor's inhibition, where the constant production of EPS and growth at the surface of a biofilm pushes earlier generations into the middle of the structure where conditions may no longer be adequate $[88,89]$. In Escherichia coli K12, an oxygen-sensing phosphodiesterase and associated diguanylate cyclase have been described [81], suggesting a mechanism allowing $\mathrm{O}_{2}$-stressed individuals in biofilms to stop EPS production and de-repress mobility by altering c-di-GMP levels; in P. aeruginosa PA01, the anaerobic regulator Anr may also interact with QS regulation in response to altering $\mathrm{O}_{2}$ levels [91]. Finally, QS regulation may impose a direct cost under some conditions, as many environmental and clinical isolates of $P$. aeruginosa have been found to have defective QS regulatory systems [92].

\section{Concluding statement}

Our desire to understand the underlying molecular biology of the novel biofilm-forming Wrinkly Spreader, an adaptive mutant isolated from radiating populations of $P$. fluorescens SBW25 in static microcosms, uncovered a pathway linking mutations affecting c-di-GMP levels to the production of cellulose which forms the main matrix component of the biofilm. Although this analysis was aided by availability of the genome sequence, our current review of the coding potential of the genome suggests that $P$. fluorescens SBW25 may also have QS regulation capability. The interaction between intracellular regulatory networks involving key regulators such as 
Ta b le. Benefits of linking individual regulatory networks with community-based decision and enforcement for the production of biofilms

\begin{tabular}{|l|l|}
\hline $\begin{array}{l}\text { Individual sensing } \\
\text { and decision }\end{array}$ & $\begin{array}{l}\text { To integrate various environmental chemical and physical signals to confirm } \\
\text { that individual bacteria are in the appropriate circumstances and position for } \\
\text { attachment and biofilm formation. C-di-GMP homeostasis linked to other } \\
\text { networks to integrate oxygen sensing, metabolic status, energy reserves, } \\
\text { nutrient availability, etc. } \\
\text { Although individual bacteria can express biofilm matrix components, there is } \\
\text { no defence against competitors (cheaters) using these and avoiding the cost of } \\
\text { production. }\end{array}$ \\
\hline $\begin{array}{l}\text { Community decision } \\
\text { and control }\end{array}$ & $\begin{array}{l}\text { To implement the cooperative investment of all appropriately-positioned } \\
\text { bacteria in the formation of a biofilm for mutual benefit. } \\
\text { As the initial expression of quorum signals within a population of bacterial } \\
\text { cells is stochastic, and if the population is also heterogeneous in terms of cell } \\
\text { position and status, there is the chance that QS will force some members to } \\
\text { cooperate when they might otherwise decide not to do so. }\end{array}$ \\
\hline $\begin{array}{l}\text { Individual and } \\
\text { Community interaction } \\
\text { decisions. } \\
\text { Interactions allow individual bacteria to opt-in to community activity when they } \\
\text { are ready and can benefit from this investment. Poorly-positioned or stressed } \\
\text { bacteria can also opt-out from the inappropriate demands of the comfortable } \\
\text { majority during the initiation of biofilm formation and in developed structures } \\
\text { when individuals may no longer occupy optimal positions. Depending on the } \\
\text { relative strengths of the individual and community regulatory systems, the } \\
\text { interaction might also allow the adjustment of individual investment resulting } \\
\text { from altered conditions, new construction costs resulting from damage, and } \\
\text { prevent the development of cheaters. }\end{array}$ \\
\hline
\end{tabular}

c-di-GMP with intracellular QS regulation provides additional benefits to both individual bacteria and communities during biofilm-formation. The acquisition of genome sequences is commonplace today and is often the starting point in investigating complex bacterial regulatory networks and behaviours. However, retrospective inspection of genomes can reveal additional elements which were not considered earlier, adding to our understanding of how bacteria interact with their environment and with each other.

The new challenge in understanding biofilmformation by $P$. fluorescens SBW25 and related pseudomonads is to determine the relative importance of environmental signals, QS regulation and mutation in the colonisation of new environments and adaptation over evolutionarily-relevant time scales. A better understanding of this will be of particular relevance to medical microbiology, where bacteria are able to colonise tissues in chronic infections by overcoming the immune system and avoiding antibiotics through biofilm-formation and mutation.

Acknowledgments. This work was supported by Abertay University; A.J. Spiers is also member of the Scottish Alliance for Geoscience Environment and Society (SAGES). O.V. Moshynets was also supported by NATO SPS 984834 . We cordially thank the Directors of the Institute of Molecular Biology and Genetics of NAS of Ukraine and the Zabolotny Institute of Microbiology and Virology of NAS of Ukraine for their assistance in the preparation of this review and their support of on-going collaborative research with Abertay University. 


\section{АНАЛІЗ c-di-GMP I МОЖЛИВОГО ПОЧУТТЯ КВОРУМУ В Pseudomonas fluorescens SBW25: ЗВ'ЯЗОК МІЖ ВНУТРІШНЬО- І МІЖКЛІТИННОЮ РЕГУЛЯЦІЕЮ СПРИЯЄ КООПЕРАТИВНІЙ ПОВЕДІНЦІ В УГРУПОВАННІ І ФОРМУВАННЮ БІОПЛІВКИ}

О. В. Мочинеиь ${ }^{1}$, Д. Фостер ${ }^{2}$,

C. О. Карахім ${ }^{3}$, К. МакЛохлін ${ }^{4}$, С. П. Рогальський, С. Ю. Римар ${ }^{1}$, Г. П. Волинець ${ }^{1}$ Е. Д. Спайрс ${ }^{4 \bowtie}$

${ }^{1}$ Інститут молекулярної біології і генетики НАН України, Київ; e-mail: moshynets@gmail.com; e-mail: galina.volinetc@gmail.com ${ }^{2}$ Оксфордський університет, Госпіталь ім. Джона Редкліфа, Велика Британія; e-mail: dona.foster@ndm.ox.ac.uk;

${ }^{3}$ Інститут біохімії ім. О. В. Палладіна, НАН України, Київ; e-mail: laserlab@biochem.kiev.ua; ${ }^{4}$ Школа науки, інжинірингу і технологій, Абертейський університет, Велика Британія; e-mail: mclaughlinkimberley@gmail.com;

凶e-mail: a.spiers@abertay.ac.uk;

${ }^{5}$ Інститут біоорганічної хімії і нафтохімії НАН України, Київ; e-mail: sergey.rogalsky@gmail.com

Успішність бактеріальної колонізації складних еконіш вимагає індивідуальної відповіді на зміни умов на мікрорівні так само як i кооперацію на рівні угруповання для продукції таких великомасштабних структур як біоплівки. Координація індивідуальних відповідей i відповідей угруповання може бути досягнута шляхом зв'язування внутрішньоклітинних сенсорних і регуляторних систем, опосередкованих біс-(3',5')-циклічним димерним гуанозинмонофосфатом (c-di-GMP) та іншими сполуками індивідуумів із міжклітинною регуляцією - почуттям кворуму (ПК), що контролює популяцію. Накопичується все більше доказів того, що формування біоплівки багатьма псевдомонадами регулюється як внутрішньоклітинними, так i міжклітинними регуляторними системами, хоча в разі модельної Pseudomonas fluorescens SBW25 Wrinkly Spreader, у котрій мутації, що підвищують рівні c-di-GMP, призводять до створення міцної целюлозної біоплівки на кордоні розділу фаз повітря-рідина, не було виявлено ніякого свідоцтва залучення кворумзалежної регуляції. Проте наш недавній огляд геномy P. fluorescens SBW25 виявив потенційний ПК-залежний регуляторний шлях та інші ПКзалежні гени, пов'язані з гомеостазом c-di-GMP, а молекули ПК-сигналінгу було ідентифіковано в культурі. Ці дані свідчать про можливий зв'язок між c-di-GMP-регуляцією і ПК у P. fluorescens SBW25, що дозволяє проводити більш складний і гнучкий контроль продукції целюлози і утворення біоплівки за колонізації грунтів і еконіш, асоційованих з рослинами, - природними середовищами існування $P$. fluorescens SBW25.

К л ючо в і слов а: циклічний димерний гуанозинмонофосфат (c-di-GMP), ацилгомосеринлактон (AHL), бактеріальна целюлоза, біоплівки, Pseudomonas, почуття кворуму.

АНАЛИЗ С-di-GMР И ВОЗМОЖНОГО
ЧУВСТВА КВОРУМА У РsеUdomonas
fluorescens SBW25: СВЯЗЬ МЕЖДУ
ВНУТРИ- И МЕЖКЛЕТОЧНОЙ
РЕГУЛЯЦИЕЙ СПОСОБСТВУЕТ
КООПЕРАТИВНОМУ
ПОВЕДЕНИЮ В СООБЩЕСТВЕ И
ФОРМИРОВАНИЮ БИОПЛЁНКИ

Е. В. Мочиней, Д. Фостер², С. А. Карахим К. МакЛохлин ${ }^{4}$, С. П. Рогальский С. Е. Рымарь ${ }^{1}$, Г. П. Вольннеи ${ }^{1}$, Э. Д. Спайpc ${ }^{4 凶}$

${ }^{1}$ Институт молекулярной биологии и генетики НАН Украины, Киев; e-mail: moshynets@gmail.com; e-mail: galina.volinetc@gmail.com ${ }^{2}$ Оксфордский университет, Госпиталь им. Джона Редклифа, Великобритания; e-mail: dona.foster@ndm.ox.ac.uk;

${ }^{3}$ Институт биохимии им. А. В. Палладина НАН Украины, Киев; e-mail: laserlab@biochem.kiev.ua;

${ }^{4}$ Школа науки, инжиниринга и технологий, Абертейский университет, Великобритания; e-mail: mclaughlinkimberley@gmail.com; 凹e-mail: a.spiers@abertay.ac.uk;

${ }^{5}$ Институт биоорганической химии и нефтехимии НАН Украины, Киев; e-mail: sergey.rogalsky@gmail.com

Успешность бактериальной колонизации сложных экониш требует индивидуального ответа на изменения условий на микроуровне рав- 
но как и кооперацию на уровне сообщества для продукции таких крупномасштабных структур как биоплёнки. Координация индивидуальных ответов и ответов сообщества может быть достигнута путем связывания внутриклеточных сенсорных и регуляторных систем, опосредованных бис- $\left(3^{\prime}, 5^{\prime}\right)$-циклическим димерным гуанозинмонофосфатом (c-di-GMP) и другими соединениями индивидуумов $\mathrm{c}$ межклеточной регуляцией - чувством кворума (ЧК), контролирующем популяцию. Накапливается всё больше доказательств того, что формирование биопленки многими псевдомонадами регулируется как внутриклеточными, так и межклеточными регуляторными системами, хотя в случае модельной Pseudomonas fluorescens SBW25 Wrinkly Spreader, у которой мутации, повышающие уровни c-di-GMP, приводят к созданию прочной целлюлозной биоплёнки на границе раздела фаз воздух-жидкость, не было обнаружено никакого свидетельства вовлечения кворумзависимой регуляции. Однако наш недавний обзор генома P. fluorescens SBW25 выявил потенциальный ЧК-зависимый регуляторный путь и другие ЧК-зависимые гены, связанные с гомеостазом c-di-GMP, а молекулы ЧК-сигналинга были идентифицированы в культуре. Эти данные свидетельствуют о возможной связи между c-diGMP-регуляцией и ЧК у P. fluorescens SBW25, что позволяет проводить более сложный и гибкий контроль продукции целлюлозы и образования биопленки при колонизации почв и экониш, ассоциированных с растениями, - естественными средами обитания $P$. fluorescens SBW25.

К лючевы е слова: циклический димерный гуанозинмонофосфат (c-di-GMP) ацилгомосеринлактон (AHL), бактериальная целлюлоза, биоплёнки, Pseudomonas, чувство кворума.

\section{References}

1. Nadell CD, Xavier JB, Foster KR. The sociobiology of biofilms. FEMS Microbiol Rev. 2009; 33(1): 206-224.

2. Nadell CD, Drescher K, Foster KR. Spatial structure, cooperation and competition in biofilms. Nat Rev Microbiol. 2016; 14(9): 589600.

3. Galloway WR, Hodgkinson JT, Bowden SD, Welch M, Spring DR. Quorum sensing in Gram- negative bacteria: small-molecule modulation of AHL and AI-2 quorum sensing pathways. Chem Rev. 2011; 111(1): 28-67.

4. Coggan KA, Wolfgang MC. Global regulatory pathways and cross-talk control Pseudomonas aeruginosa environmental lifestyle and virulence phenotype. Curr Issues Mol Biol. 2012; 14(2): 47-70.

5. Stacy AR, Diggle SP, Whiteley M. Rules of engagement: defining bacterial communication. Curr Opin Microbiol. 2012; 15(2): 155-161.

6. Garg N, Manchanda G, Kumar A. Bacterial quorum sensing: circuits and applications. Antonie Van Leeuwenhoek. 2014; 105(2): 289305.

7. Irie Y, Roberts AEL, Kragh KN, Gordon VD, Hutchison J, Allen RJ, Melaugh G, Bjarnsholt T, West SA, Diggle SP. The Pseudomonas aeruginosa PSL Polysaccharide Is a Social but Noncheatable Trait in Biofilms. MBio. 2017; 8(3). pii: e00374-17.

8. Moshynets OV, Spiers AJ. Viewing biofilms within the larger context of bacterial aggregations, in: Microbial biofilms Importance and applications, Dhanasekaran D, Thajuddin N (Eds), InTech Publishers, Rijeka, Croatia, 2016.

9. Rainey PB, Travisano M. Adaptive radiation in a heterogeneous environment. Nature. 1998; 394(6688): 69-72.

10. Spiers AJ. A mechanistic explanation linking adaptive mutation, niche change, and fitness advantage for the wrinkly spreader. Int $J$ Evol Biol. 2014; 2014: 675432.

11. Koza A, Kusmierska A, McLaughlin K, Moshynets O, Spiers AJ. Adaptive radiation of Pseudomonas fluorescens SBW25 in experimental microcosms provides an understanding of the evolutionary ecology and molecular biology of A-L interface biofilm formation. FEMS Microbiol Lett. 2017; 364(12).

12. Kirisits MJ, Parsek MR. Does Pseudomonas aeruginosa use intercellular signalling to build biofilm communities? Cell Microbiol. 2006; 8(12): 1841-1849.

13. Williams P, Cámara M. Quorum sensing and environmental adaptation in Pseudomonas aeruginosa: a tale of regulatory networks and multifunctional signal molecules. Curr Opin Microbiol. 2009; 12(2): 182-191. 
14. Haussler S, Fuqua C. Biofilms 2012: new discoveries and significant wrinkles in a dynamic field. J Bacteriol. 2013; 195(13):29472958.

15. Waters CM, Lu W, Rabinowitz JD, Bassler BL. Quorum sensing controls biofilm formation in Vibrio cholerae through modulation of cyclic diGMP levels and repression of vpsT. $J$ Bacteriol. 2008; 190(7): 2527-2536.

16. Schmid N, Suppiger A, Steiner E, Pessi G, Kaever V, Fazli M, Tolker-Nielsen T, Jenal U, Eberl L. High intracellular c-di-GMP levels antagonize quorum sensing and virulence gene expression in Burkholderia cenocepacia H111. Microbiology. 2017; 163(5): 754-764.

17. Rainey PB, Bailey MJ. Physical and genetic map of the Pseudomonas fluorescens SBW25 chromosome. Mol Microbiol. 1996; 19(3): 521533.

18. Spiers AJ, Field D, Bailey M, Rainey PB. Notes on designing a partial genomic database: The PfSBW25 Encyclopaedia, a sequence database for Pseudomonas fluorescens SBW25. Microbiology. 2001; 147(Pt 2): 247-249.

19. Silby MW, Cerdeño-Tárraga AM, Vernikos GS, Giddens SR, Jackson RW, Preston GM, Zhang XX, Moon CD, Gehrig SM, Godfrey SA, Knight CG, Malone JG, Robinson Z, Spiers AJ, Harris S, Challis GL, Yaxley AM, Harris D, Seeger K, Murphy L, Rutter S, Squares R, Quail MA, Saunders E, Mavromatis K, Brettin TS, Bentley SD, Hothersall J, Stephens E, Thomas CM, Parkhill J, Levy SB, Rainey PB, Thomson NR. Genomic and genetic analyses of diversity and plant interactions of Pseudomonas fluorescens. Genome Biol. 2009; 10(5): R51.

20. Spiers AJ. Bacterial evolution in simple microcosms, in: Microcosms: Ecology, Biological Implications and Environmental Impact, Microbiology Research Advances Series, C.H. Harris (Ed), Nova Publishers, Hauppauge, NY, USA, 2013.

21. Campilongo R, Fung RKY, Little RH, Grenga L, Trampari E, Pepe S, Chandra G, Stevenson CEM, Roncarati D, Malone JG. One ligand, two regulators and three binding sites: How KDPG controls primary carbon metabolism in Pseudomonas. PLoS Genet. 2017; 13(6): e1006839.

22. Grenga L, Chandra G, Saalbach G, Galmozzi CV, Kramer G, Malone JG. Analyzing the Complex
Regulatory Landscape of Hfq - an Integrative, Multi-Omics Approach. Front Microbiol. 2017; 8: 1784.

23. Buckling A, Craig Maclean R, Brockhurst MA, Colegrave N. The Beagle in a bottle. Nature. 2009; 457(7231): 824-829.

24. Lenski RE. Evolution in action: a 50,000-generation salute to Charles Darwin. Microbe. 2011; 6(1): 30-33.

25. Kawecki TJ, Lenski RE, Ebert D, Hollis B, Olivieri I, Whitlock MC. Experimental evolution. Trends Ecol Evol. 2012; 27(10): 547-560.

26. Mann EE, Wozniak DJ. Pseudomonas biofilm matrix composition and niche biology. FEMS Microbiol Rev. 2012; 36(4): 893-916.

27. Häussler S. Multicellular signalling and growth of Pseudomonas aeruginosa. Int J Med Microbiol. 2010; 300(8): 544-548.

28. Wolcott R, Costerton JW, Raoult D, Cutler SJ. The polymicrobial nature of biofilm infection. Clin Microbiol Infect. 2013; 19(2): 107-112.

29. Spiers AJ, Arnold DL, Moon CD, Timms-Wilson TM. A survey of A-L biofilm formation and cellulose expression amongst soil and plantassociated Pseudomonas isolates, in: Bailey MJ, Lilley AK, Timms-Wilson TM, editors. Microbial ecology of aerial plant surfaces. CABI: 121-131.

30. Ude S, Arnold DL, Moon CD, Timms-Wilson T, Spiers AJ. Biofilm formation and cellulose expression among diverse environmental Pseudomonas isolates. Environ Microbiol. 2006; 8(11): 1997-2011.

31. Robertson M, Hapca SM, Moshynets O, Spiers AJ. Air-liquid interface biofilm formation by psychrotrophic pseudomonads recovered from spoilt meat. Antonie Van Leeuwenhoek. 2013; 103(1): 251-259.

32. Spiers AJ, Deeni YY, Folorunso AO, Koza A, Moshynets O, Zawadzki K. Cellulose expression in Pseudomonas fluorescens SBW25 and other environmental pseudomonads. In: Van De Ven TGM, Godbout L, editors. Cellulose - Medical, Pharmaceutical and Electronic Applications, 2013. InTech Publishers: 1-26.

33. King EO, Ward MK, Raney DE. Two simple media for the demonstration of pyocyanin and fluorescin. J Lab Clin Med. 1954; 44(2): 301-307.

34. Spiers AJ, Kahn SG, Bohannon J, Travisano M, Rainey PB. Adaptive divergence in experimental populations of Pseudomonas fluorescens. 
I. Genetic and phenotypic bases of wrinkly spreader fitness. Genetics. 2002; 161(1): 33-46.

35. Green JH, Koza A, Moshynets O, Pajor R, Ritchie MR, Spiers AJ. Evolution in a test tube: rise of the Wrinkly Spreaders. J Biol Educ. 2011;45(1): 54-59.

36. Spiers AJ. Wrinkly-Spreader fitness in the two-dimensional agar plate microcosm: maladaptation, compensation and ecological success. PLoS One. 2007; 2(8): e740.

37. Koza A, Moshynets O, Otten W, Spiers AJ. Environmental modification and niche construction: developing $\mathrm{O}_{2}$ gradients drive the evolution of the Wrinkly Spreader. ISME J. 2011; 5(4): 665-673.

38. Kuśmierska A, Spiers AJ. New Insights into the Effects of Several Environmental Parameters on the Relative Fitness of a Numerically Dominant Class of Evolved Niche Specialist. Int $J$ Evol Biol. 2016; 2016: 4846565.

39. Day RL, Laland KN, Odling-Smee FJ. Rethinking adaptation: the niche-construction perspective. Perspect Biol Med. 2003; 46(1): 80-95.

40. Huang WE, Ude S, Spiers AJ. Pseudomonas fluorescens SBW25 biofilm and planktonic cells have differentiable Raman spectral profiles. Microb Ecol. 2007; 53(3): 471-474.

41. Van Valen L. A new evolutionary law. Evolution Theory. 1973; 1: 1-30.

42. Morris JJ, Lenski RE, Zinser ER. The Black Queen Hypothesis: evolution of dependencies through adaptive gene loss. MBio. 2012; 3(2). pii: e00036-12.

43. Parsek MR, Greenberg EP. Sociomicrobiology: the connections between quorum sensing and biofilms. Trends Microbiol. 2005; 13(1): 27-33.

44. West SA, Griffin AS, Gardner A, Diggle SP. Social evolution theory for microorganisms. Nat Rev Microbiol. 2006; 4(8): 597-607.

45. Gehrig SM. Adaptation of Pseudomonas fluorescens SBW25 to the air-liquid interface: a study in evolutionary genetics. DPhil thesis, University of Oxford, Oxford, UK, 2005.

46. Römling U. Molecular biology of cellulose production in bacteria. Res Microbiol. 2002; 153(4): 205-212.

47. Saxena IM, Brown RM Jr. Cellulose biosynthesis: current views and evolving concepts. Ann Bot. 2005; 96(1): 9-21.

48. Römling U, Galperin MY. Bacterial cellulose biosynthesis: diversity of operons, subunits, products, and functions. Trends Microbiol. 2015; 23(9): 545-557.

49. Spiers AJ, Bohannon J, Gehrig SM, Rainey PB. Biofilm formation at the air-liquid interface by the Pseudomonas fluorescens SBW25 wrinkly spreader requires an acetylated form of cellulose. Mol Microbiol. 2003; 50(1): 15-27.

50. Franklin MJ, Douthit SA, McClure MA. Evidence that the algI/algJ gene cassette, required for $\mathrm{O}$ acetylation of Pseudomonas aeruginosa alginate, evolved by lateral gene transfer. J Bacteriol. 2004; 186(14): 4759-4773.

51. Arrebola E, Carrión VJ, Gutiérrez-Barranquero JA, Pérez-García A, Rodríguez-Palenzuela P, Cazorla FM, de Vicente A. Cellulose production in Pseudomonas syringae pv. syringae: a compromise between epiphytic and pathogenic lifestyles. FEMS Microbiol Ecol. 2015; 91(7). pii: fiv071.

52. McLaughlin K, Folorunso AO, Deeni YY, Foster D, Gorbatiuk O, Hapca SM, Immoor C, Koza A, Mohammed IU, Moshynets O, Rogalsky S, Zawadzki K, Spiers AJ. Biofilm formation and cellulose expression by Bordetella avium $197 \mathrm{~N}$, the causative agent of bordetellosis in birds and an opportunistic respiratory pathogen in humans. Res Microbiol. 2017; 168(5): 419-430.

53. Moshynets OV, Koza A, Dello Sterpaio P, Kordium VA, Spiers AJ. Up-dating the Cholodny method using PET films to sample microbial communities in soil. Biopolym Cell. 2011; 27(3): 199-205.

54. Spiers AJ, Rainey PB. The Pseudomonas fluorescens SBW25 wrinkly spreader biofilm requires attachment factor, cellulose fibre and LPS interactions to maintain strength and integrity. Microbiology. 2005; 151(Pt 9): 28292839.

55. Goymer P, Kahn SG, Malone JG, Gehrig SM, Spiers AJ, Rainey PB. Adaptive divergence in experimental populations of Pseudomonas fluorescens. II. Role of the GGDEF regulator WspR in evolution and development of the wrinkly spreader phenotype. Genetics. 2006; 173(2): 515-526.

56. Bantinaki E, Kassen R, Knight CG, Robinson Z, Spiers AJ, Rainey PB. Adaptive divergence in experimental populations of Pseudomonas fluorescens. III. Mutational origins of wrinkly spreader diversity. Genetics. 2007; 176(1): 441453. 
57. Malone JG, Williams R, Christen M, Jenal U, Spiers AJ, Rainey PB. The structure-function relationship of WspR, a Pseudomonas fluorescens response regulator with a GGDEF output domain. Microbiology. 2007; 153(Pt 4): 980-994.

58. Ross P, Weinhouse H, Aloni Y, Michaeli D, Weinberger-Ohana P, Mayer R, Braun S, de Vroom E, van der Marel GA, van Boom JH, Benziman M. Regulation of cellulose synthesis in Acetobacter xylinum by cyclic diguanylic acid. Nature. 1987; 325(6101): 279-281.

59. Römling U, Gomelsky M, Galperin MY. C-diGMP: the dawning of a novel bacterial signalling system. Mol Microbiol. 2005; 57(3): 629-639.

60. Jenal U, Malone J. Mechanisms of cyclic-diGMP signaling in bacteria. Annu Rev Genet. 2006; 40: 385-407.

61. Hengge R. Principles of c-di-GMP signalling in bacteria. Nat Rev Microbiol. 2009; 7(4): 263-273.

62. Lin Chua S, Liu Y, Li Y, Jun Ting H, Kohli GS, Cai Z, Suwanchaikasem P, Kau Kit Goh K, Pin Ng S, Tolker-Nielsen T, Yang L, Givskov M. Reduced intracellular c-di-GMP content increases expression of quorum sensingregulated genes in Pseudomonas aeruginosa. Front Cell Infect Microbiol. 2017; 7: 451.

63. Moscoso JA, Jaeger T, Valentini M, Hui K, Jenal U, Filloux A. The diguanylate cyclase SadC is a central player in Gac/Rsm-mediated biofilm formation in Pseudomonas aeruginosa. J Bacteriol. 2014; 196(23): 4081-4088.

64. Cheng $X$, de Bruijn I, van der Voort $M$, Loper JE, Raaijmakers JM. The Gac regulon of Pseudomonas fluorescens SBW25. Environ Microbiol Rep. 2013; 5(4): 608-619.

65. McDonald MJ, Gehrig SM, Meintjes PL, Zhang XX, Rainey PB. Adaptive divergence in experimental populations of Pseudomonas fluorescens. IV. Genetic constraints guide evolutionary trajectories in a parallel adaptive radiation. Genetics. 2009; 183(3): 1041-1053.

66. McDonald MJ, Cooper TF, Beaumont HJ, Rainey PB. The distribution of fitness effects of new beneficial mutations in Pseudomonas fluorescens. Biol Lett. 2011; 7(1): 98-100.

67. Koza A, Hallett PD, Moon CD, Spiers AJ. Characterization of a novel air-liquid interface biofilm of Pseudomonas fluorescens SBW25. Microbiology. 2009; 155(Pt 5): 1397-1406.
68. Lind PA, Farr AD, Rainey PB. Experimental evolution reveals hidden diversity in evolutionary pathways. eLife. 2015; 4: e07074.

69. Hottes AK, Freddolino PL, Khare A, Donnell ZN, Liu JC, Tavazoie S. Bacterial adaptation through loss of function. PLoS Genet. 2013; 9(7): e1003617.

70. Udall YC, Deeni Y, Hapca SM, Raikes D, Spiers AJ. The evolution of biofilm-forming Wrinkly Spreaders in static microcosms and drip-fed columns selects for subtle differences in wrinkleality and fitness. FEMS Microbiol Ecol. 2015; 91(6). pii: fiv057.

71. Gal M, Preston GM, Massey RC, Spiers AJ, Rainey PB. Genes encoding a cellulosic polymer contribute toward the ecological success of Pseudomonas fluorescens SBW25 on plant surfaces. Mol Ecol. 2003; 12(11): 3109-3121.

72. Giddens SR, Jackson RW, Moon CD, Jacobs MA, Zhang XX, Gehrig SM, Rainey PB. Mutational activation of niche-specific genes provides insight into regulatory networks and bacterial function in a complex environment. Proc Natl Acad Sci USA. 2007; 104(46): 18247-18252.

73. Laue BE, Jiang Y, Chhabra SR, Jacob S, Stewart GS, Hardman A, Downie JA, O'Gara F, Williams P. The biocontrol strain Pseudomonas fluorescens F113 produces the Rhizobium small bacteriocin, N-(3-hydroxy-7-cis-tetradecenoyl) homoserine lactone, via HdtS, a putative novel $\mathrm{N}$-acylhomoserine lactone synthase. Microbiology. 2000; 146(Pt 10): 2469-2480.

74. Elasri M, Delorme S, Lemanceau P, Stewart G, Laue B, Glickmann E, Oger PM, Dessaux Y. Acyl-homoserine lactone production is more common among plant-associated Pseudomonas spp. than among soilborne Pseudomonas spp. Appl Environ Microbiol. 2001; 67(3): 1198-1209.

75. Bassler BL, Losick R. Bacterially speaking. Cell. 2006; 125(2): 237-246.

76. Wagner VE, Iglewski BH. P. aeruginosa Biofilms in CF Infection. Clin Rev Allergy Immunol. 2008; 35(3): 124-134.

77. Ueda A, Wood TK. Connecting quorum sensing, c-di-GMP, pel polysaccharide, and biofilm formation in Pseudomonas aeruginosa through tyrosine phosphatase TpbA (PA3885). PLoS Pathog. 2009; 5(6): e1000483.

78. Malone JG, Jaeger T, Spangler C, Ritz D, Spang A, Arrieumerlou C, Kaever V, Landmann R, 
Jenal U. YfiBNR mediates cyclic di-GMP dependent small colony variant formation and persistence in Pseudomonas aeruginosa. PLoS Pathog. 2010; 6(3): e1000804.

79. Cha C, Gao P, Chen YC, Shaw PD, Farrand SK. Production of acyl-homoserine lactone quorumsensing signals by gram-negative plantassociated bacteria. Mol Plant Microbe Interact. 1998; 11(11): 1119-1129.

80. Farrand SK, Qin Y, Oger P. Quorum-sensing system of Agrobacterium plasmids: analysis and utility. Methods Enzymol. 2002; 358: 452-484.

81. Koveal D, Clarkson MW, Wood TK, Page R, Peti W. Ligand binding reduces conformational flexibility in the active site of tyrosine phosphatase related to biofilm formation A (TpbA) from Pseudomonas aeruginosa. J Mol Biol. 2013; 425(12): 2219-2231.

82. Hornung C, Poehlein A, Haack FS, Schmidt M, Dierking K, Pohlen A, Schulenburg $\mathrm{H}$, Blokesch M, Plener L, Jung K, Bonge A, KrohnMolt I, Utpatel C, Timmermann G, Spieck E, Pommerening-Röser A, Bode E, Bode HB, Daniel R, Schmeisser C, Streit WR. The Janthinobacterium sp. HH01 genome encodes a homologue of the $V$. cholerae CqsA and $L$. pneumophila LqsA autoinducer synthases. PLoS One. 2013; 8(2): e55045.

83. Tiaden A, Spirig T, Hilbi H. Bacterial gene regulation by $\alpha$-hydroxyketone signaling. Trends Microbiol. 2010; 18(7): 288-297.

84. Sonnleitner E, Haas D. Small RNAs as regulators of primary and secondary metabolism in Pseudomonas species. Appl Microbiol Biotechnol. 2011; 91(1): 63-79.

85. Ackermann M. A functional perspective on phenotypic heterogeneity in microorganisms. Nat Rev Microbiol. 2015; 13(8): 497-508.

86. Rainey PB, Rainey K. Evolution of cooperation and conflict in experimental bacterial populations. Nature. 2003; 425(6953): 72-74.

87. Popat R, Crusz SA, Messina M, Williams P, West SA, Diggle SP. Quorum-sensing and cheating in bacterial biofilms. Proc Biol Sci. 2012; 279(1748): 4765-4771.

88. Xavier JB, Foster KR. Cooperation and conflict in microbial biofilms. Proc Natl Acad Sci USA. 2007; 104(3): 876-881.

89. Baquero F, Lemonnier M. Generational coexistence and ancestor's inhibition in bacterial populations. FEMS Microbiol Rev. 2009; 33(5): 958-967.

90. Tuckerman JR, Gonzalez G, Sousa EH, Wan X, Saito JA, Alam M, Gilles-Gonzalez MA. An oxygen-sensing diguanylate cyclase and phosphodiesterase couple for c-di-GMP control. Biochemistry. 2009; 48(41): 9764-9774.

91. Hammond JH, Dolben EF, Smith TJ, Bhuju S, Hogan DA. Links between Anr and Quorum Sensing in Pseudomonas aeruginosa Biofilms. J Bacteriol. 2015; 197(17): 2810-2820.

92. Heurlier K, Dénervaud V, Haas D. Impact of quorum sensing on fitness of Pseudomonas aeruginosa. Int J Med Microbiol. 2006; 296(23): 93-102. 